\title{
Character Education as a Means of Second Language Development in Talented Children: A Study of Sociolinguistic
}

\author{
Afnita 1 , Dedi Saputra², Ridha Hasnul Ulya 3, Efrianto 4 \\ DOI: $10.35445 /$ alishlah.v13i3.996
}

\begin{tabular}{|c|c|}
\hline Article Info & Abstract \\
\hline $\begin{array}{l}\text { Keywords: } \\
\text { Gifted children; } \\
\text { Second lanquaqe; } \\
\text { Character education; } \\
\text { Sociolinguistics }\end{array}$ & $\begin{array}{l}\text { This study aims to describe and explain the role of character education in } \\
\text { helping the development of a second language in gifted children based on } \\
\text { sociolinguistic studies. This study uses a qualitative method with a descriptive } \\
\text { analysis approach. The data in this study were obtained from the analysis of } \\
\text { conversations or dialogues and the development of the Dini Suryani language of } \\
\text { third-grade students at SDN } 27 \text { /III Lolo Kecil with their peers, interacting in } \\
\text { class with the teacher and while in the family environment. Researchers found } \\
\text { that early language development is different from normal children, who tend to } \\
\text { have a neat and well-structured use of language. Dini also uses varied and } \\
\text { appropriate vocabulary according to specific contexts. Dini also applies the use } \\
\text { of intonation and facial expressions in interacting in communicating. However, } \\
\text { Dini has a personality problem that is high egoistic, such as when she wants } \\
\text { something, she will do anything, even if she forces her will. To maximize the } \\
\text { ability of early character education is the right supporting step or method. Thus, } \\
\text { Dini can become a gifted child with a good personality. }\end{array}$ \\
\hline
\end{tabular}

Kata kunci:

Anakberbakat;

Bahasakedua;

Pendidikan karakter;

sosiolinguistik

\begin{abstract}
Abstrak
Penelitian ini bertujuan untuk mendeskripsikan dan menjelaskan peranan pendidikan karakter dalam membantu pengembangan bahasa kedua pada anak berbakat berdasarkan kajian sosiolinguistik. Penelitian ini menggunakan metode kualitatif dengan pendekatan deskriptif analisis. Data dalam penelitian ini didapatkan dari analisis percakapan atau dialog serta perkembangan bahasa Dini Suryani siswa kelas III SDN 27 /III Lolo Kecil bersama teman sebaya, berinteraksi di kelas bersama guru dan saat berada di lingkungan keluarga. Peneliti menemukan bahwa perkembangan bahasa Dini berbeda dari anak normal yang cenderung memiliki penggunaan bahasa yang tertata dengan rapi serta terstruktur dengan baik. Dini juga menggunakan kosakata yang variatif serta sesuai akan konteks tertentu. Penggunaan intonasi dan mimik wajah dalam berinteraksipun juga diterapkan Dini di dalam berkomunikasi. Meskipun demikian, Dini memiliki persoalan kepribadian yaitu egoistik yang tinggi seperti ketika ia menginginkan sesuatu segala cara akan dilakukannya meskipun dengan memaksakan kehendak. Untuk memaksimalkan kemampuan Dini, pendidikan karakter adalah langkah atau metode penunjang yang tepat. Dengan demikian, Dini dapat menjadi anakberbakat dengan kepribadian yang baik.
\end{abstract}

\footnotetext{
${ }^{1}$ Un iv ersitas Negeri Padang, Padang, In donesia

Em ail: afnita@fbs.unp.ac.id

2 Universitas Negeri Padang, Padang, In donesia

Em ail: dedisaputradhey@gmail.com

3 Univ ersitas Negeri Padang, Padang, In donesia

Em ail: ridhasnulya.unp@gmail.com

4 ST KIP Pesisir Selatan, Pesisir Selatan, In donesia

Em ail: efrianto789@gmail.com
}

Vol.13(3) December, 2021

Received: August 21, 2021; Received in revised form: September 27, 2021; Accepted: October 30, 2021; Available online: November 1, 2021

This is an open access article under a Creative Com mons Attribution-NonCom mer cial-ShareAlike 4.0 In ternational License 


\section{INTRODUCTION}

Language is a tool used by humans to interact and talk to each other. Humans need language as a means of self-expression and what we want to convey or what we know as communication. The language contains a meaning or purpose in communicating that leads to informative and communicative directions. Communicating activities contain several essential things, including a speaker, an interlocutor, and the context discussed in the conversation (Alsamiri, 2018: 12). The purpose of communication is to convey something to the interlocutor. It contains the intent and selection of words that follow the context of the communication that is being established. In communication, the message to be conveyed indeed contains something and is related to a topic. Topics will direct the speaker and the interlocutor to interact in two directions (Maryanah, 2020: 10). Communication is a matter that involves two people in it who discuss a particular subject (Tekin \& Ta, 2009: 13). In the context of communication, the role of the speech apparatus is very important to stabilize what is spoken with what is spoken. If a speech tool has problems, of course, it will hinder communication and even make communication not run smoothly.

In essence, every human being, especially children, is created with variety to complement each other and become a character inherent in humans. This difference is usually determined from several aspects, namely differences in abilities (intelligence), including inborn about the brain and cognitive, psychomotor, and affective abilities. The next difference between children is social life, which includes how life is experienced and exists in the child. This social life is related to the context of the child's interaction with the social environment in which he is located, including the family in it (Zimlich, 2016: 9). Furthermore, differences in children are caused by cultural factors. Of course, each region has its own culture and character. This character is what strengthens and strengthens a custom or habit of its citizens, including the differences that exist in children's development, especially in language and interaction. The human brain is like the central processor of a computer, such as a CPU. This causes the brain to function to control various activities or functions in all things. If someone has difficulty understanding meaning and producing language, it can be categorized that person is not classified as an average person. Cases in abnormal children, for example, are gifted (Utami \& Ashadi, 2018).

One of the cases that are often found in the context of a communication disorder is a gifted or gifted child. A gifted child is a child who is given a gift by the almighty to be different from normal humans with specific talents. This talent can be in the form of communication or language talent, painting talent, singing or musical talent, and so on. Ali \& Alrayes (2019: 8) stated that gifted or gifted children should be given special services to optimize their talents or potentials. Thus, the potential will develop and increase over time and form gifted children who have character and respect others. Gifted children can be known or detected when children are small because gifted children will show attitudes and personalities, special skills, and strong characters compared to normal children. When parents have children like that, the chances are that child is a gifted child who must be guided and trained according to the talent or gift is given to him. Don't let existing talents become meaningless or destructive to hurt the child himself. Ngiamsunthorn (2020:5) states that gifted children are very different from normal children and their behaviour or actions in life. Based on research conducted by the world's gifted child development institute, it was found that almost 90\% of gifted children have bad behaviour and are difficult to get along with and interact with the surrounding environment which results in gifted children often alienating themselves from society where they are.

Gifted children have abilities that typical children do not usually have that make these children different or not like normal children. Gifted children need special assistance or special treatment to maximize the abilities or gifts given to them (Myers-burg, 2018). Gifted children will be maximized when they can control and apply their talents well and follow the norms that apply in society (Chowdhury, 2017). Gifted children tend to be children who tend to be egoistic and behave 
badly. This is based on the excess abilities, which make their emotions stronger and not well controlled (Sharp et al., 2015). Gifted children need things that can help them control their emotions and behaviour and maximize their potential well (Sahin \& Levent, 2015). Gifted children will show their identity and can be detected from a young age; gifted children will show themselves differently from normal children (Gong et al., 2011). Gifted children tend to stand out and are very interactive and creative in a field. These fields can be in the form of language or communication, music, drawing and others (K. T. Fraser-seeto et al., 2015).

In October 2020, researchers visited elementary school number 27/III Lolo Kecil. When the research was conducted at the elementary school, the researchers initially felt that the children felt normal as usual. However, the researcher's thinking or paradigm changed when he entered the 3 rd grade of the elementary school and met a child named Dini Suryani. When the researcher interacts with Dini, Dini responds like a person who understands the language and communicates well and applies vocabulary that is not commonly used by children her age. However, behind Dini Suryani's good communication skills, it turns out that Dini is often aloof because it is difficult to interact with her peers. Dini tends to be emotional and behave badly towards her friends. When she wants something, she has to get it and the words Dini says to her friends often hurt the recesses of her friend's heart so that Dini becomes alienated. After seeing the various symptoms and behaviour of Dini. Researchers concluded that Dini is a gifted child. Because they can communicate well like a professional and have good language knowledge that children should not master at their age. Then this study aims to describe and explain how to recognize gifted children and how to properly guide gifted children to maximize their potential well and be able to interact with the community and the environment in which they are located. Therefore, this study focuses on grade 3 elementary school students, namely Dini Suryani, who has talent in interaction or communication.

Character education emphasizes education and guidance on the attitudes or behaviour of students (Potter \& Saffran, 2017). Character education emphasizes forming a person's personality that tends to be positive, enthusiastic, cheerful and following the adab and norma prevailing in society. Character education is an essential thing to be taught to the millennial generation (Aditama, 2020). Therefore, the program or plan for student character education has been applied to the 2013 curriculum, which emphasizes character-based education (Ulya, 2018, 2019; Erni, 2018). Character education will shape personality and improve personality for both normal children and children who have gifts, one of which is gifted or gifted children (Blaas, 2020). Character education is critical for gifted children to grow up with good and positive personalities and interact and communicate with their environment (K. T. Fraser-seeto et al., 2015). Character education will also encourage and direct gifted children with good and civilized personalitiesespecially when researching the behaviour of gifted children who tend to be emotional and egotistical. With the application of character education, it is hoped that gifted children can form better than before (Rinn et al., 2010). Research on gifted children is very popular because of its uniqueness that makes researchers compete to produce research on this field, and one of them is done by Muhammad Ali. In his research, Muhammad Ali found that gifted children have unique talents that are not possessed by children in general, which makes them unique. (M. Ali, 2019).

Murdock is one of the researchers who researched the realm of gifted children, focusing on the egoistic and characteristics of gifted children. Gifted children tend to be emotional, making it difficult for them to interact with the world. Many things must be done so that gifted children will become more focused, including giving special attention that will provide benefits, especially children's emotional and attitude formation (Murdock-smith, 2013). Khilie in 2013 also revealed that gifted children are a blessing and have a deficiency, and this deficiency needs to be corrected as a means to maximize abilities. In her research, Khilie found that gifted children tend not to have friends because it is difficult to interact with others. Gifted children will often be alone in navigating life in solitude (K. Fraser-seeto, 2013). The difference between this study and other 
research is that this research will provide a solution, namely character education as a step in optimizing gifted children to become gifted children with good attitudes and behaviour according to the norms prevailing in society. Because, in essence, gifted children are lucky children who are born with advantages, it's just that these advantages need to be optimized so that they are in line with the norms and principles that apply in society. In addition, the novelty of this research is in terms of research focus. Previous researchers have revealed more research in terms of psychological aspects and theories of the psychological developmental stages of gifted children. However, this study reveals the language development of gifted children associated with character education that previous researchers have never done.

\section{METHOD}

This research is a qualitative descriptive study that focuses on identifying or detecting gifted children and character education to maximise gifted children's abilities. Qualitative descriptive research aims to describe the data contained in research specifically and directed (Sugiyono, 2014). The object of this research is SDN 27/III Lolo Kecil. SDN 27/III Lolo Kecil is one of the public elementary schools in Kerinci Regency, Jambi Province. The sampling technique used in this research is purposive sampling. This technique uses criteria that have been selected by researchers, which are divided into inclusion and exclusion criteria. The inclusion criteria are the sample criteria that the researcher wants to be based on the research objectives. In contrast, the exclusion criteria are particular criteria that cause prospective respondents who meet the inclusion criteria to be excluded from the research group. Based on these criteria, it was determined that the sample of this study was an elementary school student named Dini Suryani, a gifted child who has good language skills or is talented in language.

The data from this study is the result of the transcription of communication and observations of researchers with Dini Suryani. The instruments used in this study were observation sheets and data inventory formats containing indicators of gifted children's language skills seen from two aspects, namely: linguistic and non-linguistic (mimic, expression, intonation, pronunciation). The method used in this research is observation. Observation is a method of collecting data by direct observation on the object of research (Mahsun, 2007). Observation is done by observing and recording the symptoms that appear on the object under investigation. The type of observation used in this study is participant observation. Participatory observation is a method in which the researcher is involved in the person's daily activities being observed or used as a source of research data. In this observation, the researcher was involved through communication with a child named Dini to reveal the development of the language skills of gifted children. Data will be collected from conversations that have been transcribed and analyzed between researchers, teachers, and Dini Suryani's interactions with the surrounding environment.

There are three stages in the data analysis of this research. First, data reduction are summarizing, choosing the main things, focusing on the essential things, looking for themes and patterns and removing unnecessary ones. Second, the data presented is displayed in brief descriptions, charts, and relationships between categories. By displaying data, it can make it easier to understand what happened, plan further work based on what has been understood. In addition, at this stage, the authors collect, sort, classify, synthesize, make an overview, and create an index. Third, concluding is an initial conclusion where substantial evidence is found that supports the next stage of data collection. The results of this study are displayed in the form of student conversations that are selected as the object of research, namely Dini Suryani. In the end, the data were detailed according to the role and usefulness of character education in maximizing the ability of Dini Suryani, namely children who are gifted in the field of language. 


\section{FINDINGS AND DISCUSSION}

The data presented in this discussion is a small part of the data of the research conducted. The researcher's data in the results and discussion is data that has been filtered and filtered according to the research objectives to be described to the reader, divided into several points, namely as follows.

\section{Methods for Recognizing Gifted Children}

When entering the 3rd grade of Elementary School 27/III Lolo Kecil, the researcher first asked the teacher or homeroom teacher whether there were children who were different or had something that stood out from other students. Then the homeroom teacher stated that a child named Dini Suryani was different and spoke very neatly. After listening to the statement, the researcher and teacher went into class 3 and had the following conversation:

"Teacher : Assalamualaikum warahmatullahi wabarakatuh. Good morning ladies and gentlemen, today kak Dedi will accompany and teach all of the students.

Students: Waalaikumsalam Madam. OK, ma'am, thank you. Good morning, too.

Teacher: Then,just go ahead and give the class to Mr Dedi to teach all of you.

Students: Fine, ma'am.

Researcher: How are you all good?

Students:Alright sis.

Researcher: Which Ananda Dini?

Dini: What is it, sir? Is there anything Dini can help with?

Researcher: Dini, do you know what a rhyme is?

Dini: Pantun is an old type of poetry with ab-ab rhyme. Pantun contains various elements that make the message conveyedfeel maximal.

Researcher: Applause everyone for Dini.

Dini: (cold and relaxed expression)."

From the conversation above, which the researcher conducted with Dini, it is clear that Dini's use of vocabulary in answering the researcher's questions is very mature and well-organized. Dini can and is good at assembling and arranging words in expressing his opinion. When conveying her opinion, Dini also expresses and assures that she knows the meaning of rhyme. Only I can see that after Dini answered, Early's attitude tends to be indifferent and relaxed.

"Wina: Dini, do you know what a short story is?

Dini: (silence and ignore).

Wina: Dini, answer, please!

Dini: just look at the book (while leaving his friend)."

Week after week, the researcher passed in grade 3 of this Little Lolo Elementary School. Then the researcher also found that Dini's attitude was egoistic and emotional, so she had no friends. Dini also tends to force what he wants and do various things to get it. Based on information from Dini's parents, Dini also has no friends outside of school. Dini only spends time in the room or at home.

\section{Application of Character Education in Class}

After passing the first day, researchers have proven that Dini is a talented student. Then the researcher discussed with the homeroom teacher to implement character education in the classroom to support the development of early behaviour. The researcher also asked the teacher for time to do counselling to Dini specifically to provide special character education directly to Dini. In the classroom for two weeks, the researcher applied character-based education. Conceptualize learning on religious rules and norms that apply in society. The researcher also gave special treatment to Dini, and after the class, the writer and Dini also did counselling. Although Dini 
seemed the same and challenging to communicate with at first, slowly, Dini understood and understood what it means to live in a society.

Researchers must be patient in dealing with Dini's attitude. T argeting Dini to understand and implement the character education being taught takes a relatively long time and is not as easy as turning the palm. In addition, the changes in Early Childhood were felt after a month the researchers conducted character education for Early Childhood in the classroom or directly. Researchers researched for approximately three months until finally the various things that researchers had prepared to form or maximize the abilities of gifted children, namely Dini. After doing early character education, they can interact a little with their peers. Dini began to open up to socialize and make friends. Dini is also less individualistic and more caring.

Researcher: today we learnwhile playing, right, son?

Students: Okay, Sis.

Researcher: Let's all form a team divided into 5 people.

Dini : (approaching other students to form a team). Come on, we definitely can, and cheersforour team!

Researcher: Everything is ready!

Students: Ready Sis.

After coaching Dini for a whole month, Dini's attitude in socializing with friends, teachers, and the environment has become better than before. Likewise, in Dini's language, Dini has been able to distinguish the right words to use with her friends and the choice of diction that is not appropriate for her to say. The development of Dini's second language is attached in the following conversational dialogue.

Andre: Dini, I don't know what poetry is, canyou explain?

Dini: Poetry is a series of beautiful words, the words we choose in making poetry are adjusted to our poetry. For example, if a poem is sad, we have to look sad in choosing the words as well as when reading it, my friend (Dini explains with a smile and is friendly).

Andre: So that's it, Early? Andre wants to write his assignment poem first.

Dini: Alright Dre, cheer up! (Dini also expresses friendly and caring).

Tina: Dini, I want to write a poem about Mother, so should I be sad?

Dini: Well, for Tina, you matched Tin to the theme you brought up, whether the theme was about Mother's struggle or what it was about. If it's your mother's poem but it has a theme of humor or humor, that's fine too. So Tina just adjusted it to the theme (explaining while paying attention to the eyes of the otherperson).

Tina: What's the theme, Din?

Dini: The theme is like the atmosphere you put in your poem, whether sad, happy, or sad, git.

Tina: Thank you Early.

Dini: You're welcome Tina (with a friendly smile).

From the conversation above, it can be seen that Dini can relate or interact with her friends and is more able to control herself and open up. Of course, this is a positive thing and helps in maximizing the abilities of gifted children. In addition to having language skills, Dini also has a good attitude and behaviour. 
In the results section above, researchers can observe the development of early attitudes from one stage to another. Starting from the stage of recognizing Dini that Dini is a gifted child. In this section, Dini clearly shows her attitude or behaviour that is not good in communicating and the use of language that is very prominent from her, which is very neat when asked by her teacher to describe the meaning or definition of the rhyme. At this introduction stage, Dini's attitude is frigid, not open, not accessible in communicating and unable to respect the other person. This is, of course, a negative thing that must be corrected from Dini so that the gift that is in Dini, who is a gifted child, is optimal and perfect.

The second dialogue between Dini and her classmates also shows that Dini doesn't care about asking questions. She even asked his friend to reread the lesson about short stories that the teacher had taught. Dini also shows her selfish and unhelpful attitude, which causes Dini to be less liked by her classmates. In addition, when carrying out character education in the classroom. At first, Dini looks normal and unaffected. Dini still has an unsociable attitude but with high language skills. However, as the days turn to months, Dini is finally able to slowly change her mind and understand what it means to be together and live in the community.

After carrying out character education in Dini's class, Dini seems to improve and can communicate and interact with her classmates. Dini begins to open up and experiment to bond and build relationships with her friends. Dini becomes more expressive, smiles easily and doesn't like being alone and playing with her friends. In addition, the final result is the development of an early second language in interacting with the environment to be very optimal, thanks to the application of character education. Character education based on religion and social life directs Dini to better communicate with her sociolinguistic environment.This study found the same facts as the research of Ali \& Alrayes where gifted children tend to have a potential that exists in themselves but also has shortcomings or weaknesses. Dini's strengths are in terms of language skills, but Dini's weaknesses are egoistic and individualistic and introverted, which causes Dini to be a loner and have no friends. Fraser-seeto et al. (2015) stated that gifted children generally have communication problems. This is also found in this study; Dini has difficulty expressing and interacting with her environment, is not good at language application in a conversation context. Dini is only competent in the language in theory but not in practice in social life.

One of the problems faced by Dini is self and emotional control, which is in line with Blaas' research (2021) which states that gifted children are challenged to control and manipulate attitudes or emotions. This is undoubtedly an important thing that must be improved to optimize the potential in gifted children. The application of character education to support acquiring a second language in gifted children is essential to overcome weaknesses in gifted children into an advantage. Character education will shape good attitudes and behaviour, especially in communication science for gifted children. In this case, the object of research is Dini Suryani. Character education contains various elements in it, both in the form of spiritual knowledge in religion and behavioural or ethical education following the provisions of existing norms in Indonesia and the world. Character education will direct gifted children to a definite manner and purpose and believe and open themselves about the literal meaning of humans as social beings who need each other.

\section{CONCLUSION}

Gifted children are children who have advantages or talents that exist in themselves. Gifted children are endowed with extraordinary advantages. These advantages should be maximized and honed correctly so that they are directed and become good. Teachers and parents should be obliged to direct gifted children according to the procedures to develop correctly and perfectly. One of the best and most powerful ways to develop and direct gifted children is through character education. Character education will provide direction and guidance on how to behave and act in daily life. At Dini, who is a gifted child, character education can reduce his individualism and egotistical 
attitude. Researchers hope that the results of this study can be a reference in maximizing gifted children, and the best step is to provide character education. Gifted children will form their personalities behind the potential that exists in them. Teachers and parents must collaborate in maximizing character education. Teachers do it at school and parents at home. Thus, gifted children will maximize their abilities and behave well and be accepted in society .

\section{REFERENCES}

Aditama, V. Y. (2020). Pengunaan sapaan bahasa kerinci dialek jujun. BASINDO: Journal Kajian Bahasa, Sastra Indonesia, Dan Pembelajarannya, 4, 135-143. http://creativecommons.org/licenses/BY/4.o/

Ali, H., \& Alrayes, A. (2019). The Role of Technology in Gifted and Talented Education : A Review of Descriptive and Empirical Research. Journal KNOWLEDGE, 1(1), 26-38. https://doi.org/10.18502/kss.v3i24.5165

Ali, M. (2019). Gifted and Talented Education: A Review of Relevant Literature.

Alsamiri, Y. (2018). How Learning Disabilities Teachers in The Kingdom of Saudi Arabia. Journal of Disabilities Studies, 1(1), 356-365.

Blaas, S. (2021). The Relationship Between Social-Emotional Difficulties and Underachievement of Gifted Students. Australian Journal of Guidance and Counselling, 24(2), 243-255. https://doi.org/10.1017/jgc.2014.1

Chowdhury, M. A. (2017). Towards the Achievement of a Unified , Uniform and Socially - Just ' Gifted Education' Policy Acceptable on a Global Scale. Jornal for the Education of Gifted Young Scientists, 5(March), 1-22.

Erni, E., WS, H., Thahar, H.E., \& Asri, Y. (2018). Nyanyian Panjanq Bujang Si Undang as Oral Tradition in Melayu Ethnic; An Alternative Approach for Mental Revolution. Education, Social Sciences and Technology Application in Digital Era, pp. 430-436.

Fraser-seeto, K. (2013). Pre-service teacher training in gifted and talented education: An Australian perspective. Journal of Student Engagement: Education Matters, 3(1), 29-38.

Fraser-seeto, K. T., Howard, S. J., Woodcock, S., Fraser-seeto, K., Howard, S. J., \& Woodcock, S. (2015). An Investigation of Teachers 'Awareness and Willingness to Engage with a SelfDirected Professional Development Package on Gifted and Talented Education Education. Australian Journal of Teacher Education, 4O(1), 1-12.

Gong, Y., Chow, I. H. siu, \& Ahlstrom, D. (2011). Cultural diversity in China: Dialect, job embeddedness, and turnover. Asia Pacific Journal of Management, 28(2), 221-238. https://doi.org/10.1007/s10490-010-9232-6

Iskandar. (2008). Metodologi PenelitianPendidikan dan Sosial (Kuantitatif dan Kualitatif). Gp Press.

Mahsun. (2007). Metode Penelitian Bahasa: Tahap, Strategi dan Tekniknya. Raha Grafindo Persada.

Maryanah, S. (2020). Indonesian Teachers 'Attitudes Towards Gifted Students with Low SES from Malay Background. Indonesia Journal of Disability Studies, 7(1), 110-118.

Murdock-smith, J. (2013). Understanding the Social And Emotional Needs of Gifted Children. InSight: RIVIER ACADEMIC JOURNAL, 9(2), 2-5.

Myers-burg, M. R. (2018). The Role of Dialect Words in Children's Social Decisions. University of Arkansas.

Ngiamsunthorn, P. S. (2020). Promoting creative thinking for gifted students in undergraduate mathematics. Journal of Research and Advances in Mathematics Education, 5(1), 13-25. https://doi.org/10.23917/jramathedu.v5i1.9675

Potter, C. E., \& Saffran, J. R. (2017). Exposure to multiple accents supports infants' understanding of novel accents. Cognition, 166, 67-72. https://doi.org/10.1016/j.cognition.2017.05.031

Rinn, A. N., Plucker, J. A., Stocking, V. B., Plucker, J. A., \& Stocking, V. B. (2010). Fostering Gifted Students 'Affective Development : A Look at the Impact of Academic Self-Concept A Look at the Impact of Academic Self-Concept. Journal TECPlus, 6(4), 1-15.

Sahin, F., \& Levent, F. (2015). Examining The Methods and Strategies Which Classroom Teachers Use In The Education of Gifted Students. The Online Journal of New Horizons in Education, 5(3), 69-78. 
Sharp, L. A., Clemmer, P., Sharp, L. A., \& Clemmer, P. (2015). The Neglected Readers : Differentiating Instruction for Academically Gifted and Talented Learners The Neglected Readers: Differentiating Instruction for Academically Gifted and Talented Learners. The Journal of Balanced Literacy Research and Instruction, 3(1), 1-14.

Sugiyono. (2014). Metode Penelitian Pendidikan Pendekatan Kuantitatif, Kualitatif, dan R\&D. Alfabeta.

Tekin, M., \& Ta, Ö. (2009). Analysis of the creativity level of the gifted students. ELSEVIER, 1(1), 1088-1092. https://doi.org/10.1016/j.sbspro.2009.01.196.

Ulya, Ridha Hasnul., Thahar, H.E., Asri, Y., \& Agustina, A. (2018). Cultural Manifestation in Superstition of Minanakabau Societu. Education, Social Sciences and Technology Application in Digital Era, pp. 422-429, 2018.

Ulya, Ridha Hasnul. (2019). Dimensi Keteraturan Sosial Wanita Hamil dalam Gamitan Superstisi Kubuang Tigo Baleh. Jurnal Kafa'ah, (8), Pp. 183.

Utami, H., \& Ashadi. (2018). Direct EFL Instruction for Gifted Students : A Case Study. Journal of Culture, English Language, Teaching and Literature, 18(2), 1-12.

Zimlich, S. L. (2016). Motivating Gifted Students : Technology as a Tool for Authenticity and Autonomy. International Journal of Learning, Teaching Ad Educational Research, 15(13), 111 . 